\title{
Comparative study of off-grid and grid-connected hybrid power system: issues, future prospects and policy framework
}

\author{
Bankole Adebanji, Oluwaseun Atoki, Taiwo Fasina, Oluwumi Adetan, Adewale Abe \\ Department of Electrical and Electronic Engineering, Ekiti State University, Ado Ekiti, Nigeria
}

\begin{abstract}
Article Info
Article history:

Received Dec 7, 2020

Revised Mar 9, 2021

Accepted Mar 21, 2021

\section{Keywords:}

Comparative study

Grid-connected system

Hybrid power system

Off-grid system

Policy framework

ABSTRACT

A sustainable energy system is of utmost importance for any significant development in any nation. This work identified some obstacles inhibiting rapid renewable energy growth in Nigeria and recommended some policy measures in overcoming them. Moreover, a comparative study of off-grid (OG) and grid-connected (GC) small hydro-solar photovoltaic-diesel hybrid system was carried out using Oyan river, Abeokuta, Nigeria as a case study. The hybrid components were modeled with and without the grid. The hydro solar resources data of the area were collected and analyzed using hybrid optimization model for electric renewable (HOMER) software. The simulation results proved that the GC hybrid power system is better than the OG hybrid power system in technical and economic terms depending on the location. This paper, therefore, proposed the use of OG hybrid power system for electrification of distant villages especially where extending the grid seems infeasible and the use of GC hybrid power system in the urban areas. The work will assist power sector stakeholders in making informed decisions towards the growth of hybrid power system technology in Nigeria.
\end{abstract}

This is an open access article under the CC BY-SA license.

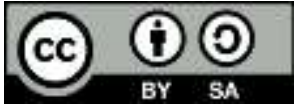

\section{Corresponding Author:}

Bankole Adebanji

Department of Electrical and Electronic Engineering

Ekiti State University, Ado-Ekiti, Nigeria

Email: bankole.adebanji@eksu.edu.ng

\section{INTRODUCTION}

A sustainable energy system is of utmost importance for any significant development in any nation. It preserves the natural resources and prevents negative environmental impacts that may be detrimental to the ecosystem now and in the future [1]-[3]. The adverse effect of global warming and change in climatic conditions as a result of heavy reliance on fossil fuels is at present a global issue [4]-[5].

Power supply in Nigeria (majorly depends on fossil fuels) is insufficient, unreliable and not sustainable. Almost half of about 200 million people are living without electricity, with majority of them dwelling in the rural areas [6]-[7]. Even most of the people that are grid-connected, experience frequent interruptions, voltage fluctuations, blackouts (that may last for days or even weeks) and perennial load scheduling [8]. This has made so many people to buy different fossil-fuel generators of different capacities to generate their own electricity. This trend has led to loss of lives with its attendant negative impacts on the economy and the ecosystem. Industrial consumers have installed generators in order to solve the problems of frequent interuptions from the grid. Some other people who find the capital and maintenance costs of these generators too high, have migrated along with their businesses to near-by countries, leading to retarding economic growth [9]. Considering the abundant renewable energy sources (RES) in almost everywhere in Nigeria, the country is in the best position to harness all these energy resources in ensuring a healthy ecosystem. However, the fluctuating nature of RES especially solar photovoltaic (PV) and wind poses a great 
challenge, a hybrid combination of two or more RES that are complementary in nature will serve as a better option for rural electrification [1]-[4].

Renewable energy hybrid power system (HPS) is pollution free and environment-benign. It consists of two or more energy resources that are complementary in nature, thereby ensuring reliable power supply in the rural setting. Researches carried out on HPS, have shown its economic viability particularly in areas where it is not geographically or economically feasible for grid-extension [1]-[16]. Two major advantages of HPS are: project cost reduction and project market value increment [10]-[11]. This can be done in either as an off-grid (OG) energy system where power is supplied to the consumers without connection to the grid for remote locations or exist as grid-connected (GC) system where excess power is supplied to the grid to complement the system. The OG and GC have so many benefits peculiar to the individual methods of connection. However, some of the factors that guide the choice of either OG or GC are [12]:

a) Accessibility and climate change

b) Economic feasibility and load factors

Off-grid (OG) hybrid power system technology produces power without being connected to the grid. These are peculiar to remote locations, where connecting them to the grid may seemingly be impossible and economically infeasible due to scattered population. Some of the disadvantages of OG are very low capacity factor, limited storage capacity and high cost of battery. The correct sizing must be done to match the operation capacity to the demand [13].

Grid-connected (GC) power system technology can be classified into two types. The first category is where the excess power generated is fed into the grid and when there is shortage, it derives supply from the grid. The second type is to operate as a utility scale managed by private organization and the power generated is fed into the grid without supply to the rural consumers. This type is best used for locations that are too far from the grid. GC eliminates the problems of (seasonal) load fluctuations and acts like infinite battery storage system [12], [14].

So many authors have also worked on the techno-economic feasibility of off-grid HPS [2]-[4], [10], [14]-[22] and grid-connected HPS [22]-[28]. The most common areas are solar photovoltaic (PV)-Wind HPS, PV-Diesel (DG) HPS, Wind-PV-DG HPS and PV-Wind- Biomass HPS [20], [25]. Very few authors worked on small hydropower (SHP)-based hybrid combinations [2].

Barakat et al, [23] worked on the feasibility of grid-connected PV- Biomass in Beni Suef, Egypt. The optimal configuration showed a high reduction in total emission and a reduced energy system investment. The study found that a grid connected PV-biomass is an effective way of emissions reduction and does not have an increase in energy system investment. Usman et al, [27] did a feasibility assessment of grid-connected PV-DG hybrid system using hybrid optimization model for electric renewable (HOMER) software for a faculty building in New Delhi, India. The work considered three different scenarios-gridconnected only, PV-Grid hybrid and PV-DG hybrid systems. The results proved that PV-Grid hybrid system is the most economical with COE of Rs $8.84 / \mathrm{kWh}$. Tomer and Tiwari [28] carried out a techno-economic feasibility of grid-connected PV hybrid system. The results proved that the proposed hybrid system is economically viable to meet up with the households demand.

Several works have been carried out on HPS; however, very few works have been published on comparative study of OG and GC hybrid power system especially in Nigeria [1]-[3], [21], [26]. This work identified some obstacles inhibiting rapid renewable energy growth in Nigeria and recommended some policy measures in overcoming them. In addition, a comparative study of off-grid (OG) and grid-connected (GC) small hydro-solar PV-Diesel hybrid system was carried out using Oyan river, Abeokuta, Nigeria as a case study.

\subsection{Renewable energy growth in Nigeria: prospects and barriers}

Nigeria is abundantly endowed with vast RES which are yet to be totally explored [21]. The available RES potentials in Nigeria, if properly harnessed are over $68000 \mathrm{MW}$ (five times the current average output of $3800 \mathrm{MW}$ ) [29]. The country is gradually moving up in the area of RES utilization. There are now some handfuls of research centres scattered all over the country, working on renewable energy technologies. Most of the research works are now targeted at improving the efficiency and reducing the energy costs. The abundant solar irradiations almost throughout the year, favours the use of solar energy-thermal and solar photovoltaic (PV). The small hydro power resources in some of the water supply dams can be used to generate electricity for rural communities. The available RES especially the solar energy and the small hydro resources can be used to form a mini-grid and grid-tied renewable hybrid power generation. Employment opportunities can be created for our young engineers through collaborative efforts in maintenance and construction of small hydropower (SHP) dams.

Some of the major constraints hindering rapid RES growth in the country are; non-awareness, lack of technology know-how, high capital cost, few research and development centres, absence of enabling 
regulations/policies and high interest rates. In order to attract foreign investors and to encourage local participation in renewable energy technology (RET) development. There is need to address these barriers though effective policy formulation.

\subsection{Nigeria's renewable energy policy formulation}

Energy policy is set towards enhancing efficient, reliable, sufficient and sustainable energy system at minimum cost. It must protect the rights to access information, the rights against indiscriminate changes in price which may discourage potential investors. This can be done through effective legalization, taxation, incentives to investors, guidelines, agreements and their policy ideologies [14]. Effective execution of energy system policies is bound to be successful if the objectives are well-outlined and implemented by the stakeholders. The stakeholders concerns in this case are local governments, private investors, international agencies, NGO's and the consumers [12]. There is need for policy alignment among the stakeholders as national policy may act as a barrier to local RES development if there is no proper integration [30].

Some of the factors needed to be considered in renewable energy technology formulation, for any meaningful development to take place in the sector are

a) Policy that places emphasy on priority/goal setting, conformity and well-stated objectives on some issues. If targets are not set and supported with appropriate measures, it is possible to give room for non-compliance and this may discourage investors from having confidence on the policy documents

b) Diversification of energy generation sources and integration of RES into the nation's energy generation mix.

\section{MATERIALS AND RESEARCH METHOD}

A techno-economic feasibility study of small hydropower (SHP)-solar photovoltaic (PV)-diesel (DG)-battery (BATT) hybrid system was done in OG and GC modes.

\subsection{Study area}

Hydro and solar resources data for the study area for twenty years period were collected from osunogun river basin development authority (OORBDA), Abeokuta and National Aeronautics and Space Administration's global satellite database respectively. The load demand was obtained through administration of questionnaires to the inhabitants. Oyan River, Nigeria, was used as a study area. It is on latitude $7^{\circ} 15^{1} 29^{\circ}$ and N $3^{\circ} 15^{1} 20 \mathrm{E}$. The daily load demand chart is as shown in Figure 1.

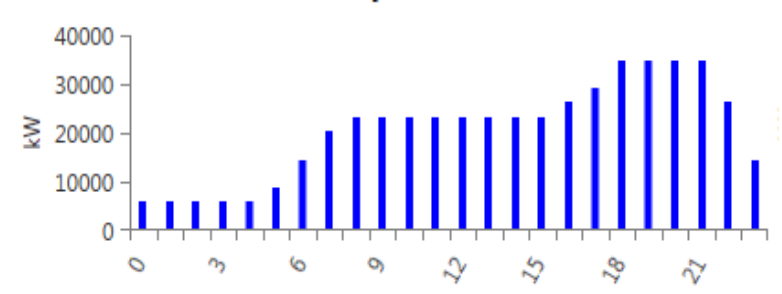

Figure 1. Abeokuta daily load profile

\subsection{Mathematical models of the HPS components}

The hybrid components were modeled as in the following sub-sections. The terms and meanings of the components used are as given in Table 1.

Table 1. Nomenclature

\begin{tabular}{cccc}
\hline Symbol & Meaninig & Symbol & Meaninig \\
\hline$P_{S H P}$ & Turbine output power & $T_{C}$ & Cell temperature \\
$\rho_{\text {water }}$ & Water density $\left(1000 \mathrm{~kg} / \mathrm{m}^{3}\right)$ & $k T$ & maximum power Temperature coefficient \\
$g$ & Acceleration due to gravity $\left(9.8 \mathrm{~m} / \mathrm{s}^{2}\right)$ & $G$ & Solar radiation in $\mathrm{kW} / \mathrm{m}^{2}$ \\
$H_{\text {net }}$ & Effective head & $C(t-1)$ & Battery capacity at previous increment \\
$Q$ & Water discharge $\left(\mathrm{m}^{3} / \mathrm{s}\right)$ & $E_{g}$ & Total energy content of oil \\
$\eta_{k}$ & Pump efficiency & $P_{B}(t)$ & Battery input /output power \\
$P_{P V}$ & PV cell output power & $\eta_{D G}$ & DG conversion efficiency \\
$P_{r-p v}$ & Rated power at reference conditions & & \\
$G_{r e f}$ & Solar radiation $\left(1000 \mathrm{~W} / \mathrm{m}^{3}\right)$ at reference & & \\
\hline
\end{tabular}


a) SHP Generator

The SHP power output is as in (1) [31].

$$
P_{S H P}=\eta_{h} \rho_{\text {water }} g H_{n e t} Q
$$

b) PV Generator Model

The power output of the PV cell, is calculated as in $\mathrm{P}_{\mathrm{PV}}$ can be calculated as in (2) [32].

$$
\mathrm{P}_{\mathrm{PV}}=\mathrm{P}_{\mathrm{r}-\mathrm{PV}}\left[\frac{\mathrm{G}}{\mathrm{G}_{\mathrm{ref}}}\right]\left[1+\mathrm{kT}\left(\mathrm{T}_{\mathrm{C}}-\mathrm{T}_{\mathrm{ref}}\right)\right]
$$

c) BATT. Model

The battery capacity, $\mathrm{C}(\mathrm{t})$ at a point in time $\mathrm{t}$, is calculated as in (3) [33].

$$
C(t)=C(t-1)-\eta_{\text {batt }}\left(\frac{P_{B}(t)}{V_{B U S}}\right) \Delta t
$$

$\mathrm{P}_{\mathrm{B}}(\mathrm{t})$ is given as in (4)

$$
P_{B}(t)=E_{g}(t)-E_{i}(t)
$$

d) DG Model

DG can be described as an energy conversion system as in (5) [34]-[37].

$$
E_{D G}=\eta_{D G} E_{f f}
$$

An assumed linear fuel consumption rate, F, for DG operation in litres/hour is given in (6) [34]-[35].

$$
F=\left(0.246 \times P_{\text {out }}\right)+\left(0.08415 \times P_{\text {Ngen }}\right) \text { litres / hour }
$$

\subsection{Research approach}

The hydro and solar resources of the study area were collected, analyzed and converted to monthly and annual data as in Table 2. Sizing and costing of the hybrid components were done using the manufacturers' sheets. The hybrid components-SHP, PV, BATT, DG and inverter were modeled with and without connecting to the grid using HOMER software. The components, hydro and solar resources data were fed into the HOMER software and simulated to obtain the optimal configuration with lowest levelised cost of energy (COE) and net present cost (NPC). The wining optimal hybrid system of the OG was then compared with that of the GC based on the total power production, economic parameters-COE, NPC, e.t.c and greenhouse gas emission. The typical HOMER model for Abeokuta is as in Figure 2.

Table 2. Averaged monthly hydro and solar resources data for oyan river, Abeokuta [36]

\begin{tabular}{cccccc}
\hline Month & $\begin{array}{c}\text { Head } \\
(\mathrm{m})\end{array}$ & $\begin{array}{c}\text { Discharge } \\
(\mathrm{L} / \mathrm{s})\end{array}$ & $\begin{array}{c}\text { Peak Sun Hour } \\
\left(\mathrm{kWh} / \mathrm{m}^{2}\right)\end{array}$ & $\begin{array}{c}\text { Temperature } \\
\left({ }^{\circ} \mathrm{C}\right)\end{array}$ & $\begin{array}{c}\text { Clearness } \\
\text { Index }\end{array}$ \\
\hline Jan. & 0.28 & 410 & 5.28 & 30.69 & 0.53 \\
Feb. & 0.25 & 360 & 5.36 & 31.21 & 0.52 \\
Mar. & 0.33 & 530 & 5.29 & 30.89 & 0.50 \\
April & 0.69 & 1350 & 5.32 & 30.28 & 0.52 \\
May & 1.10 & 4890 & 5.00 & 29.47 & 0.52 \\
June & 2.27 & 7980 & 4.48 & 28.64 & 0.48 \\
July & 2.35 & 12730 & 4.08 & 28.15 & 0.43 \\
Aug. & 2.93 & 14630 & 3.60 & 28.20 & 0.36 \\
Sept. & 2.33 & 12210 & 4.30 & 28.38 & 0.42 \\
Oct. & 1.77 & 7750 & 4.91 & 28.99 & 0.47 \\
Nov. & 1.07 & 3070 & 5.31 & 29.78 & 0.53 \\
Dec. & 0.37 & 540 & 5.27 & 30.33 & 0.53 \\
Annual Average & 1.31 & 5538 & 4.85 & 29.58 & 0.48 \\
\hline
\end{tabular}




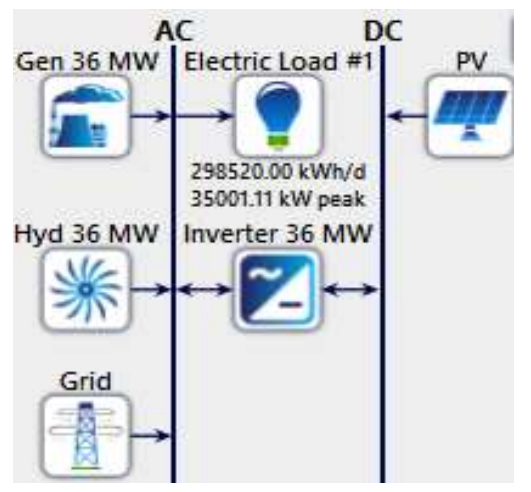

Figure 2. Solar PV-Small hydropower-diesel generator model

\section{RESULTS AND DISCUSSIONS}

\subsection{Total power, grid sales and excess electricity production consideration}

The wining configuration is PV-DG hybrid system. The power production from each connection was compared as in Figue 3. The available excess power productions on the GC were sold while the excess power productions on OG were wasted as this was not possible through the grid. The total power production is more in $\mathrm{GC}$ than that of $\mathrm{OG}$ while the excess electricity is higher in $\mathrm{OG}$ than GC hybrid system.

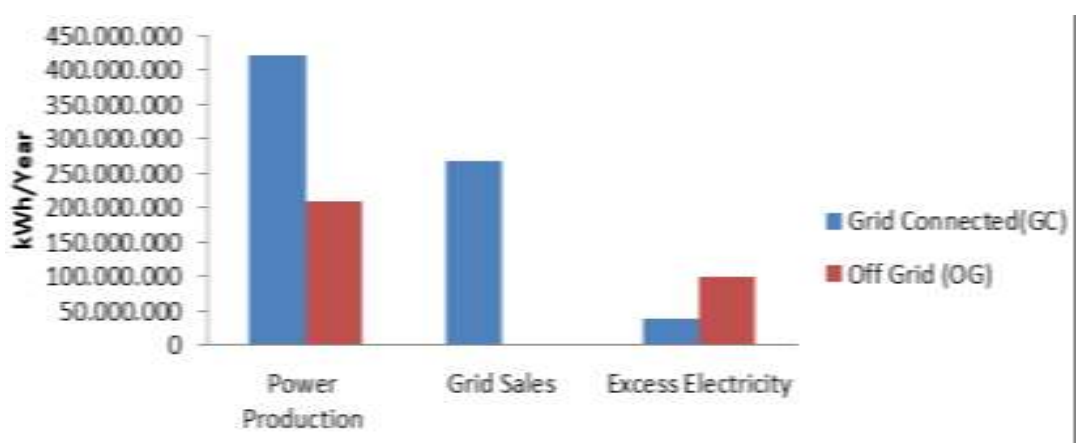

Figure 3. Comparative chart of total power production, grid sales and excess electricity

\subsection{Economic parameter analysis}

Economic comparison of grid-connected PV-DG with off-grid PV-DG is made considering net present cost (N.P.C.), levelised cost of energy (L.C.O.E), return on investment (R.O.I.) and Discounted Payback Period. This is as shown in Table 3. It can be seen that R.O.I. of off-grid is negative which means it is a loss. This affects other financial metrics as they indicate non-applicable (N/A). The grid-connected PVDG discounted payback period is 5.98 years as off-grid PV-DG cannot break even. Thus, economically, gridconnected PV-DG is better than off-grid PV-DG and also the best configuration of all configurations.

Table 3. Economic parameter consideration

\begin{tabular}{ccccc}
\hline Topology & LCOE $(\$ / \mathrm{kWh})$ & NPC $(\$)$ & ROI $(\%)$ & Discounted Payback Period (yr) \\
\hline Grid connected -solar PV-DG & -0.224 & $-109 \mathrm{~m}$ & 16.1 & 5.98 \\
Off-Grid solar PV-DG & 0.295 & $416 \mathrm{~m}$ & -18.9 & N/A \\
\hline
\end{tabular}

\subsection{Greenhouse gas emission considerations}

Greenhouse gas emission of OG and GC was compared as in Figure 4. More emission is safed in off-grid topology based on the fact that Grid connected -solar PV-DG supplies to both the required load demand and the remaining to the unreliable grid while Off-Grid solar PV-DG supplies to the load demand alone. 


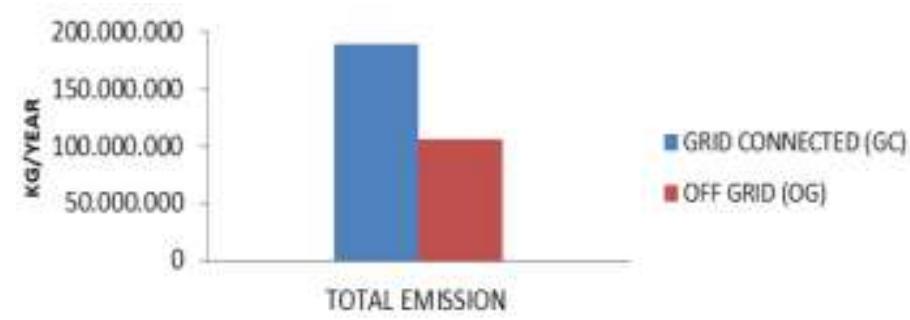

Figure 4. Comparative chart of of emission

\section{CONCLUSION}

This work identified some obstacles inhibiting rapid renewable energy growth in Nigeria and recommended some policy measures in overcoming them. Considering the harmful effects of global warming and its attendant's environmental effects, it is imperative to shift from fossil-fuelled energy sources to environment-friendly renewable energy sources. The work also carried out a comparative study of SHP-Solar PV-DG hybrid system in both off-grid and on-grid modes using Abeokuta, Nigeria as a study area. The comparison metrics are based on the total power production, economic parameters-COE, NPC, and greenhouse gas emission. Grid-connected (GC) system showed a reduction in NPC, COE and an increase in power production and green house gas emission. The simulation results showed that the GC system is better than the OG system in technical and economic terms depending on the location. This paper, therefore, proposed the use of OG hybrid power system for electrification of distant villages especially where extending the grid seems infeasible and the use of GC hybrid power system in the urban areas. The federal government needs to carry the state, local and even the consumers along in policy formulation. There is need for collaborative efforts among the policy stakeholders to formulate effective energy policies towards rapid development of renewable energy technologies for sustainable development. The government also needs to subsidise renewable energy components to be able to compete favourably with the fossil-fuelled power generation. This will indeed encourage local and foreign investors in power generation projects. The work will assist power sector stakeholders in making informed decisions towards HPS technology development in Nigeria.

\section{ACKNOWLEDGMENTS}

All the authors wish to express their gratitudes to all staff and students of Ekiti State University, Ado-Ekiti, Nigeria for the use of their laboratories and research centres.

\section{REFERENCES}

[1] Oyedepo, Sunday Olayinka, et al., "Towards a sustainable electricity supply in Nigeria: the role of decentralized renewable energy system," European Journal of Sustainable Development Research, vol. 2, no.4, pp. 1-31, 2018, doi: 10.20897/EJOSDR\%2F3908.

[2] B. Adebanji, G. A. Adepoju, P. K., Olulope, E. T. Fasina, and O. Adetan, "Feasibility and Optimal Design of a Hybrid Power System for Rural Electrification for a Small village in Nigeria," International Journal of Electrical and Computer Engineering (IJECE), vol. 10, no. 6, pp. 6214-6224, 2020, doi: 10.11591/ijece.v10i6.pp6214-6224.

[3] B. Adebanji, G. A. Adepoju, O. O. Fagbohun, and P. K. Olulope, "Development of Simulation and Optimization model for rural Electrification," Journal of Scientific Research and Report, vol. 15, no. 16, pp. 1-13, 2017, doi: 10.9734/JSRR/2017/36109.

[4] A. B. Esan, A. F. Agbetuyi, O. Ogboreda, K. Ogbeide, A. A. Awelewa A. A, and Afolabi, "Reliability assessments of an islanded hybrid pv-diesel battery system for a typical rural community in Nigeria," Heliyon, pp. 1-13, 2020.

[5] M. Kdair Abd, "Economic viability and profitability assessments of WECS," International Journal of Electrical and Computer Engineering, vol. 10, no. 2, pp. 1220-1228, April, 2020, doi: 10.1016/j.heliyon.2019.e01632.

[6] IEA, International Energy Agency, “Key world energy statistics, International Energy Agency,” Paris France, 2017.

[7] Nigeria Energy Forum, Accelerating access to sustainable energy for all-scaling up sustainable rural electrification in Nigeria, Lagos, $17^{\text {th }}-18^{\text {th }}$ April, 2018.

[8] V. K. Abaniki, S. O. Ikheloa, and F. Okodele, "Overview of the Nigerian power sector," American Journal of Engineering Research, vol. 7, pp. 253-263, 2018.

[9] J. O. Dada, "Towards understanding the benefits and challenges of smart/ micro-grid for electricity supply system in Nigeria," Renewable and Sustainable Energy Reviews, vol. 38, pp. 1003-1014, 2014, doi: 10.1016/j.rser.2014.07.077. 
[10] W. Gorman, A. Mills, M. Blinger, R. Wiser, N. G. Singhal, E. Ela, and E. Oshaughressy, "Motivation and options for deploying hybrid generator-plus-battery projects within the bulk power system," The Electricity Journal vol. 33, no.5, pp. 1-15, 2020, doi: 10.1016/j.tej.2020.106739.

[11] Iwayemi, C. Diji, B. Awotide, A., Adenikanjju, and P. Obute, "Towards sustainable universal access in Nigeria," CPEEL, 2014, doi: 10.1016/j.tej.2019.106691.

[12] S. O. Oyedepo, "Towards achieving energy for sustainable development in Nigeria," Renewable Energy Reviews, vol. 34, pp. 255-272, 2014, doi: 10.1016/j.rser.2014.03.019.

[13] G. D. Braun," State policies for collaborate local renewable integration," Electricity journal, vol. 33, no. 1, pp. 1-9, 2020, doi: 10.1016/j.tej.2019.106691.

[14] I. H. Zarma, "Hydropower resources in Nigeria," https/wwwresearchgate.net/particle/hydro resources in Nigeria, 2017.

[15] M. S. Okundamiya and O. Omoro, "Viability of a photovoltaic-diesel-battery hybrid power system in Nigeria," Iranian Journal of Energy and Environment, vol. 6, no. 1, pp. 5-12, 2015. doi: 10.5829/idosi.ijee.2015.06.01.03.

[16] L. Olatomiwa, S. Mekhilef, and O. S. Olumakin, "Hybrid renewable power supply for rural health clinics (RHC) in six geo-political zones of Nigeria," Sustainable Energy Technologies and Assessments, vol. 13, pp. 1-12, 2016, doi: 10.1016/j.seta.2015.11.001

[17] D. E. Babatunde, O. M. Babatunde,M. U. Emozemuwire, I. H. Denwigwe, T. E. Okharedia, and O. J. Omodora, "Feasibility analysis of an off-grid photovoltaic-battery energy system for a farm facility," International Journal of Electrical and Computer Engineering (IJECE), vol. 10, no. 3, pp. 2874-2883, 2020, doi: 10.11591/ijece.v10i3.pp2874-2883.

[18] H. Masrur, H. O. R. Howlader, M. E. Lofty, K. R. Khan, J. M. Gerrero, and T. Senjyu, "Analysis of technoeconomic environmental suitability of an isolated microgrid system located in a remote island of Bangladesh," Sustainability, vol. 12, no. 7, pp. 1-27, 2020, doi: 10.3390/su12072880.

[19] K. Merugaperumal, D. Ajay, and P. Raj, "Feasibility design and techno-economic analysis of hybrid renewable energy system for rural electrification,” Solar Energy, vol. 188, pp. 1068-1083, 2019, doi; 10.1016/j.solener.2019.07.008.

[20] J. Back, J. Collingsworth, S. Clemner, J. Gignec, M. Jacobs, P. Garcia, and S. Scattler, "The economic feasibility of solar and storage systems in Illinois," The Electricity Journal, vol. 33, no. 1, pp. 1-5, 2020, doi: 10.1016/j.tej.2019.106689.

[21] B. Adebanji, "Development of a hybrid power system model for rural electrification," an unpublished Ph.D thesis submitted to the Department of Electronic and Electrical Engineering, Ladoke Akintola University of Technology, Ogbomoso, Nigeria, 2019.

[22] D. P. Kamadinya, P. Balachandra, and N. H. Ravindranath, "Grid-connected versus stand-alone energy systems for decentralized power-A review of literature," Renewable and Sustainable Energy Reviews, vol. 13, no. 8, pp. 20412050, 2009, doi; 10.1016/j.rser.2009.02.002.

[23] S. Barakat, M. M. Samy, B. E. Magdy, and I. W. Wael, "Feasibility study of grid-connected pv-biomass integrated energy system in Egypt,” Int. J. Energy, Electric Power Syst. pp. 1-11, 2016, doi; 10.1515/ijeeps-2016-0056.

[24] G. Varshney, D. S. Chauhan, and M. P. Dave, "Evaluation of power quality issues in grid-connected PV systems," International Journal of Electrical and Computer Engineering (IJECE), vol. 6, no. 4, pp. 1412-1420, 2016, doi; 10.11591/ijece.v6i4.pp1412-1420.

[25] V. Lavanya and N. S., Kumar, "Control strategies for seamless transfer between the grid-connected and islanded modes of a micro grid system," International Journal of Electrical and Computer Engineering (IJECE), vol. 10, no. 5, pp. 4490-4506, 2020, doi; 10.11591/ijece.v10i5.pp4490-4506.

[26] O. D. Atoki, B. Adebanji, A. Adegbemile, E. T. Fasina, and O. D. Akindele, "Sustainable Energy Growth in Nigeria: The role of Grid-connected hybrid power system," International Journal of Scientific and Technology Research, vol.9, no. 9, pp. 274-281, 2020, doi: 10.13140/RG.2.2.27257.39524.

[27] M., Usman, M., T. Khan, A. S, and S. Ali, "Techno-economic analysis of hybrid solar-diesel-grid connected power generation system," Journal of Electrical Systems and Information Technology, vol. 5, no. 3, pp. 653-662, June 2018, doi: 10.1016/j.jesit.2017.06.002.

[28] V. Tomer and G. N. Tiwari, "Techno-economic evaluationof grid-connected PV system for households with feed in tariff and time of day tariffs regulation in New Delhi-a sustainable approach," Renewable Sustainable Energy, vol. 70, pp. 822-835, 2017, doi: 10.1016/j.rser.2016.11.263.

[29] A. S. Sambo, "Energy crisis in Nigeria: engineers' proactive steps towards energy self-sufficiency," Lecture as the first in the series of the distinguished lectures in honor of Engr. Dr. EJ. S. Uujanban, at the University of Benin, Benin city, on the 6th day of April, 2018.

[30] I. O. Marcellus, "Development planning in Nigeria: reflections on the national economic empowerment and development strategy (NEEDS) 2003-2007," J. Soci. Sci., pp. 197-210, 2009, doi: 10.1080/09718923.2009.11892740.

[31] G. Z. Somano and G. Shunki, "Design and modeling of hybrid PV-micro hydro power generation case study Jimma zone," American Journal of Electrical Power and Energy System, vol. 2, pp. 43-48, 2017, doi: 10.11648/J.EPES.20160506.15.

[32] Y. Hungxing, "Optimal sizing method for stand-alone hybrid solar-wind system with LPSP technology by using genetic algorithm," Solar Energy, vol. 82, pp. 354-367, 2008, doi: 10.1016/j.solener.2007.08.005. 
[33] E. Koutroulis, D. Kolokosa, A. Potirakis, and K. kalaitzakis, "Methodology for optimal sizing of stand alone photovoltaic/wind-generator systems using genetic algorithms," Solar Energy vol. 80, no. 9, pp. 1072-1088, 2006, doi: 10.1016/j.solener.2005.11.002.

[34] A. Vahabzadeh, F. Separi, M. Samkush, and M. Jafari "Optimal sizing of hybrid energy resources for electricity distant rural areas of Iran," Paper no. 03222, CIRED 2012 Workshop: Integration of Renewables into the Distribution Grid-Lisbon. pp. 29-30, 2007.

[35] O. Kour, "Technical and Economic Analysis of a hybrid power system: a case study for a village in India," International Journal for Research in Applied Science and Engineering Technology, vol. 6, no. 5, pp. 2043-2049, June, 2019.

[36] BORDA, "Benin-Owena River Basin Development Authority," Hydrological Year Book, p. 2, 2011.

[37] I. A. Jumare, R. Bhandan, and A. Zarga, "Assessment of a decentralized grid connected photovoltaic (PV)-windbiogas hybrid powersystem in northern Nigeria," Energy, Sustainability and Society, pp. 1-25, 2020, doi: 10.1186/s13705-020-00260-7.

\section{BIOGRAPHIES OF AUTHORS}

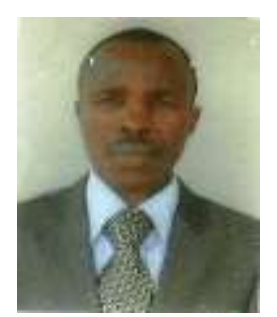

Bankole Adebanji graduated with a B. Eng. degree in Electrical and Electronic Engineering in 1997 from Ekiti State University, Ado-Ekiti, He holds M.Tech.degree and Ph.D degree (Power System Engineering and Machine) from Ladoke Akintola University of Technology (LAUTECH), Ogbomoso, Nigeria in 2010 and 2019 respectively. He is currently lecturing in theElectrical and Electronic Engineering department of Ekiti State University, Ado-Ekiti, Nigeria.

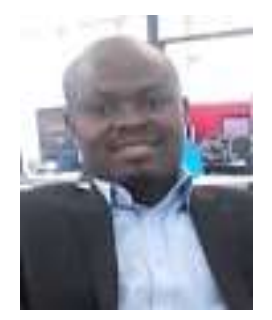

Oluwaseun Damilola Atoki received his B. Eng degree in Electrical and Electronic Engineering at University of Sunderland, United Kingdom in 2014 and also holds certification in solar PV installations and supervision at National Power Training Institute of Nigeria (NAPTIN) in 2019. He is currently a M. Eng. student at Ekiti State University, Ekiti State, Nigeria. His research interest includes Integrated Renewable Energy System.

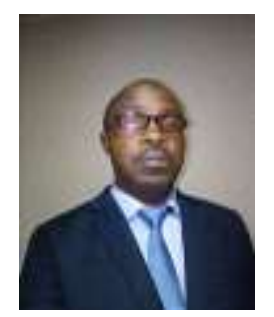

Fasina Emmanuel Taiwo received B. Eng. from Ekiti State University Ado Ekiti, Nigeria in 1998 and M. Tech. from Ladoke Akintola University of Technology, Ogbomoso, Nigeria in 2012. He completed his Ph.D. from Cardiff University, UK in 2019. He is currently a lecturer in Ekiti State University, Ado Ekiti, Nigeria.

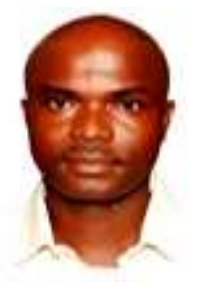

Oluwumi Adetan holds a Bachelor of Engineering (B.Eng.) degree in Electrical and Electronic Engineering from Ekiti State University, Nigeria), an (M.Eng.) degree in Electrical and Electronic Engineering (Communication Option) from the Federal University of Technology, Akure, Nigeria. He completed in 2014 his Doctoral degree in Electronic Engineering from the University of KwaZulu-Natal, South Africa. He is currently a Senior Lecturer in the Department of Electrical and Electronic Engineering, Ekiti State University, Nigeria.

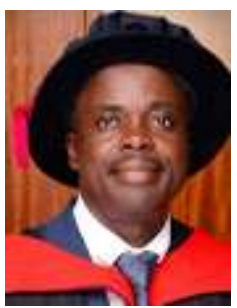

Adewale Abe had his B. Eng. degree in Electrical and Electronic Engineering in 1999 from Ekiti State University) Ado Ekiti, bagged his M. Eng from University of Benin, Benin City in 2005. He completed his Ph.D Degree) in Electronic Systems Engineering from University of Essex, United Kingdom in 2018. He is currently a Senior Lecturer in the Department of Electrical and Electronic Engineering, Ekiti State University, Nigeria. 